\title{
High-resolution seismic reflection profiling: an aid for resolving the Pleistocene stratigraphy of a buried valley in central Illinois, USA
}

\author{
Andrew J. STUMPF, Ahmed ISMAIL \\ Illinois State Geological Survey, Prairie Research Institute, University of Illinois, Champaign, IL, USA \\ E-mail: astumpf@illinois.edu
}

\begin{abstract}
High-resolution seismic reflection (HRSR) data acquired over the Pesotum Bedrock Valley in central Illinois, USA, helped construct the seismic stratigraphy of a valley fill and the overlying sediments. Integrating these data with drilling and borehole geophysics allowed us to develop a seismo-stratigraphic classification for sediments on undulating and folded bedrock. Seven seismo-stratigraphic units that overlie the bedrock surface were characterized. Seismic units A and B include glacial sediments of multiple Pleistocene glaciations above the Pesotum Bedrock Valley, which completely mask the feature. Seismic units C-F, the valley fill, primarily include tills and glacial lake sediment deposited during the earliest Pleistocene glaciations and preglacial alluvium and colluvium that is draped over in situ weathered bedrock. The preservation of conformable-lying glacial and preglacial deposits and paucity of sand and gravel in the buried valley strongly indicate that little or no incision by glacial meltwaters has occurred. These observations contrast markedly with interpretations from buried valleys elsewhere in North America and northern Europe where valley fills contain significant deposits of sand and gravel in tunnel valleys. The HRSR data assisted the characterization and analysis of heterogeneous sedimentary sequences over a buried valley where existing subsurface information was limited. The extent of Pleistocene-age glacial lakes is inferred from the lateral continuity of silt and clay units.
\end{abstract}

\section{INTRODUCTION}

Buried valleys are prominent features that have been identified in the Pleistocene sedimentary record from glaciated terrains worldwide, especially in the Northern Hemisphere. They have been the focus of recent studies, especially in North America and Europe, because they hold significant supplies of groundwater and economic shallow gas, contain aggregate for construction, may be pathways for the movement of contaminated groundwater and typically have a more complete sedimentary record that can be used to model past geological processes and Earth's climatic conditions. Determining the architecture and internal complexity of these heterogeneous deposits is of critical importance in understanding how the natural resources can be utilized in an economical and environmentally responsible manner.

By definition, buried valleys are deep channel-form features incised into the underlying sediment or bedrock by flowing water or glacial scouring, which have been completely filled in and covered over by more recent deposits of unconsolidated sediment (Type I valleys; Saines, 1968). They are present near the land surface, but because of the aforementioned sediment mask, these features have no geomorphological expression at the land surface. Therefore, they cannot be mapped from surficial geological data. Also, they are particularly difficult to delineate from the available geologic logs in boreholes drilled for water resources and engineering testing in these areas. Typically, these boreholes do not fully penetrate the valley fills, are irregularly spaced and/or are too few in number. Collecting the required subsurface information that alone would thoroughly delineate these features is too expensive.

Owing to these limitations, complementary geophysical methods have been employed to investigate buried valleys
(Hunter and others, 1984; Gabriel and others, 2003; Jørgensen and others, 2003). These non-invasive methods have been effective in delineating their morphology and dimensions. Buried valleys are typically long, extending several kilometers to tens of kilometers, hundreds of meters to kilometers wide and are several tens to hundreds of meters deep (e.g. Huuse and Lykke-Andersen, 2000; Stackebrandt, 2009; Cummings and others, 2012). The glacially derived sediments that fill buried valleys often have a lithology, mineralogy, consistency and moisture content that differs significantly from the surrounding bedrock or sediments into which the valleys have been incised. These differences allow many geophysical methods to be used in their study. The geophysical methods provide laterally continuous information across the buried valleys.

Of these geophysical methods, high-resolution seismic reflection (HRSR) surveys have been the primary method used in North America (Sharpe and others, 2003; Ahmad and others, 2009; Pugin and others, 2009; Pugin and Pullan, 2011) and northern Europe (Huuse and others, 2003; Kristensen and others, 2007; Auken and others, 2009; Reitner and others, 2010) to delineate buried glacial valleys. The use of HRSR surveys has increased in the past decade because seismic land-streamer technologies have been developed that are more efficient than the conventional method of planting geophones (Van der Veen and Green, 1998; Van der Veen and others, 2001). Subsequently, data from HRSR surveys enable a better delineation of finegrained sediments (silt and clay) from coarse-grained sediments (medium to very coarse sand and gravel) if the deposits being imaged are sufficiently thick relative to the wavelength of the applied seismic signals (Bradford and others, 1998; Musil and others, 2002; Kilner and others, 
2005; Jørgensen and Sandersen, 2008; Pugin and Pullan, 2011). The analysis and interpretation of the HRSR data allow for quantitative descriptions of heterogeneity of sedimentary sequences in buried valleys that can be utilized to develop conceptual models for buried-valley incision (e.g. Cummings and others, 2012).

In northern and central Illinois, HRSR surveys have been conducted over the last 10 years to delineate bedrock valley systems concealed by thick sequences of glacial sediment deposited during multiple Pleistocene glaciations (Pugin and others, 2004; Ismail and Sargent, 2006; Ismail and others, 2012). This geophysical method was found to be best suited to subsurface investigations in Illinois because of the relatively high clay and moisture contents in the glacial sediment and the presence of shale bedrock, subsurface properties that limit the use of many other geophysical methods, including electrical resistivity and electromagnetic methods (Ahmad, 2006; Smith and Sjogren, 2006). Likewise, ground-penetrating radar was found to have a very limited depth of penetration, typically less than a few meters (Larson and others, 1999).

Typically, the HRSR data are collected as part of an integrated research program where other types of geophysical data are collected and exploratory drilling is conducted. Without this complementary subsurface information, the development of a conceptual geological framework from the HRSR data is difficult due to the complex character of valley-fill sediments (cf. Kilner and others, 2005; Ahmad, 2006; Pugin and others, 2009). Commonly, the buried valleys are filled with heterogeneous deposits containing fluid-saturated porous and permeable sand and gravel interstratified with low-porosity and low-permeability diamicton, very fine sand, silt or clay.

This study will demonstrate the application of HRSR profiling using a land streamer to delineate a buried valley (Pesotum Bedrock Valley) and characterize its filling sediments where limited subsurface information from drilling or down-hole geophysical surveys is available. This research was undertaken as part of an integrated geological and geophysical investigation to support the construction of a regional-scale hydrogeological model for central Illinois. The HRSR profiling will provide laterally continuous images of the subsurface that can be compared with the geological and geophysical data collected in boreholes along the lines of survey. These results can be used to delineate the architecture and structure of the buried valley, which may hold insight into the subaerial and subglacial processes that were active in front of, or under, glaciers.

\section{REGIONAL GEOLOGY}

Over the last $\sim 1 \mathrm{Ma}$, the landscapes in Illinois have been repeatedly modified by glaciers and their associated meltwaters during at least three major glacial periods during the Pleistocene epoch. In central Illinois, the present-day topography has little or no resemblance to the preglacial landscape that formed over many millions of years since 4the Pennsylvanian period that ended 299 Ma ago. Prior to the first glacial advance during the pre-Illinois Episode, the landscape was characterized by rolling to gently undulating uplands that were dissected by an integrated system of valleys deeply incised into the bedrock (Fig. 1a; Herzog and others, 1994). These valleys contained steeply sloping walls much like the modern-day Ozark Plateau in Missouri, USA
(Kolata, 2010). The bedrock surface has since been buried completely by thick successions of sediment deposited during glacial and interglacial periods.

Prior to the first glacial advance into Illinois, the bedrock valleys in central Illinois formed part of an expansive drainage network (Teays-Mahomet Bedrock Valley System; Fidlar, 1943; Horberg, 1945; Ver Steeg, 1946) containing rivers and streams with headwaters in the Appalachian Mountains (Kempton and others, 1991) that flowed several hundreds of miles to the west, draining into the Middle Illinois and Mackinaw Bedrock Valleys (Fig. 1a) in western Illinois. At this time, the Ancient Mississippi River flowed in the Middle Illinois and Mackinaw Bedrock Valleys. The Pesotum Bedrock Valley, the focus of this study, was a northwest-southeast-trending tributary of the Mahomet Bedrock Valley (Fig. 1b). The Pesotum Bedrock Valley is a preglacial valley incised into Pennsylvanian-age shale and siltstone bedrock that is present on the western flank of the La Salle Anticlinorium. Along this structure folded Silurianage dolomite and limestone (444-398 Ma old) outcrops at the bedrock surface (Nelson, 1995).

A conceptual geological framework for the Pleistocene glaciations and the preglacial period in central Illinois has been developed from the available subsurface information. These data were collected from exploratory boreholes drilled to install groundwater-monitoring wells and domestic water supply wells, including three control boreholes (Figs 1 and $2 \mathrm{a}-\mathrm{c})$ completed for this study (Stumpf and Dey, in press).

During the Pleistocene glacial advances, ice flowed along and across the bedrock valleys in central Illinois to terminal margins in western and southern Illinois (Curry and others, 2011). Glaciers of the earliest advances during the preIllinois and Illinois Episodes disrupted and diverted the preglacial drainage patterns in these bedrock valleys (Kempton and others, 1991; Soller and others, 2000; Stumpf and Dey, in press). In the major valleys, meltwater flowing away from the ice margins carried large amounts of coarsegrained sediment (sand and gravel) down-valley. In the tributary valleys, the meltwater was ponded behind dams of ice or sediment. Where the meltwater entered lakes, deposits of finer-grained sediment (fine sand, silt and clay) accumulated. Subsequently, after these glacial advances, the valleys were completely filled in with the outwash and lake sediment, and thick layers of clayey diamicton (till).

Later glacial advances during the Illinois and Wisconsin Episodes deposited additional sediments over the buried valleys (Kempton and others, 1991; Hansel and Johnson, 1996; Stumpf and Dey, in press). In one area of central Illinois, predominantly west-east-trending end moraines (Fig. 1b), formed during the last glaciation (Wisconsin Episode) ending $\sim 10000$ years ago, overlie the buried bedrock valleys, completely obscuring the topography of older land surfaces. Specifically, over the Pesotum Bedrock Valley, deposits of glacial sediment ( $\sim 50 \mathrm{~m}$ thick) lie above the valley, which is filled by $35 \mathrm{~m}$ of glacial and nonglacial sediment (Fig. 2a-c).

The sediments encountered in the Pesotum Bedrock Valley have been classified by Stumpf and Dey (in press) to lithostratigraphic units in the same manner as Willman and Frye (1970) and Hansel and Johnson (1996). Diamicton, silt and clay, and sand and gravel were deposited during multiple glacial and nonglacial periods. The oldest sediments (diamicton, silt and sand, and sand and gravel) are preglacial in origin, classified to the undifferentiated lowermost 


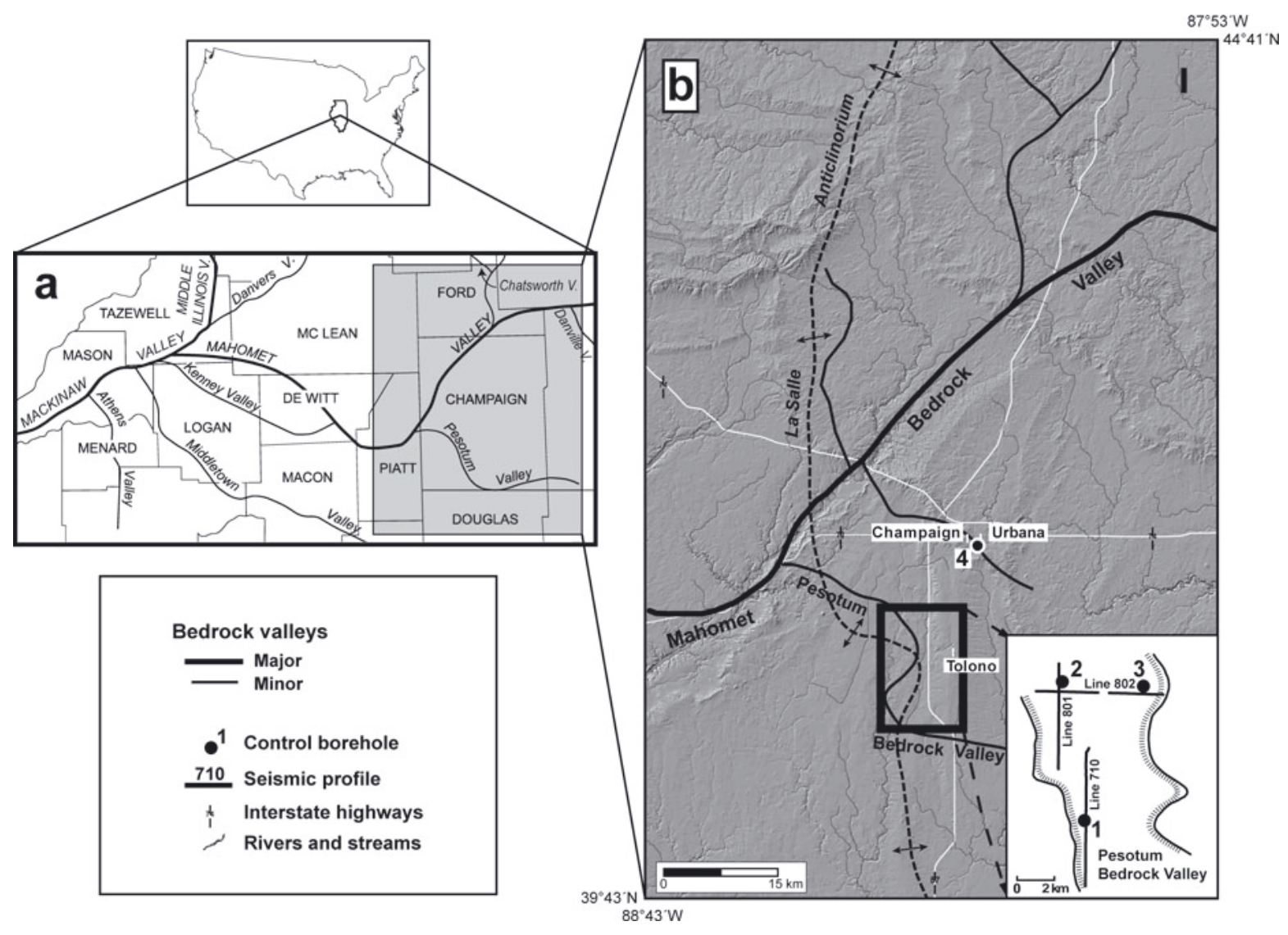

Fig. 1. Location of the study area in central Illinois, USA. (a) Regional view of the Mahomet aquifer covering 15 counties in central Illinois. The axes of major bedrock valleys are shown. (b) Axes of bedrock valleys superimposed on a hill-shaded digital elevation model representing the topography of the land surface. End moraines form the concave-shaped ridges shown on the model and mark the position of ice margins of glacial advances during the Wisconsin Episode. Glaciers during the Wisconsin Episode reached their terminal positions $\sim 60 \mathrm{~km}$ south of the study area. The study area is outlined by the black box. On the inset map, the three seismic reflection surveys and three control boreholes (discussed in the text) are located over the Pesotum Bedrock Valley. A fourth borehole was drilled over another bedrock valley under the cities of Champaign and Urbana.

unit of the Banner Formation (Fig. 2a-c), were encountered at the bottom of bedrock valley and compose alluvial or colluvial deposits. These sediments overlie bedrock that is commonly soft and friable, suggesting that the bedrock surface was exposed to a period of surficial weathering before being buried.

In the Pesotum Bedrock Valley, the preglacial sediment is stratigraphically overlain by diamictons (tills) and glacial lake sediment (Fig. 2a-c) deposited during the pre-Illinois Episode (marine isotope stages (MIS) 16 ( 620 ka) and 12 ( 430 ka); Johnson, 1986; Hansel and McKay, 2010). These sediments are classified to the Banner Formation of Willman and Frye (1970). The deposits of glacial lake sediment are conformably overlain by tills. Massive deposits of clay with silt at the bottom part of the glacial lake sequence coarsen upwards into laminated or bedded silt and clay with drop stones and then interbedded silt, very fine sand and diamicton lying under massive diamicton (till). The uppermost till of the Banner Formation, the Hillery Member till, contains remnants of a paleosol that contains a Bt soil horizon (cf. Hall and Anderson, 2000), represented by intense oxidation, wellexpressed soil structure and clay films, and leaching of primary carbonate minerals thought to be part of the Yarmouth Geosol of Leverett (1898) and Willman and Frye (1970). The Yarmouth Geosol developed during an interglacial that was part of a $\sim 230 \mathrm{ka}$ long period (Yarmouth Episode) following the end of the pre-Illinois Episode glaciation (Hansel and McKay, 2010). The Pesotum Bedrock Valley has a more complete record of the pre-Illinois Episode glaciation than the larger Mahomet Bedrock Valley to the north (Fig. 1) where erosion during later glacial advances removed much of the pre-Illinois stratigraphy (Stumpf and Dey, in press).

In the Pesotum Bedrock Valley, the Hillery Member till is overlain by sand and gravel (outwash) and/or diamicton and silt and clay (glacial lake sediment) (Fig. 2a-c) deposited during the Illinois Episode (MIS 6) between 190 and $130 \mathrm{ka}$ (Curry and others, 2011). These sediments are classified to the Pearl and Glasford Formations of Willman and Frye (1970). The diamicton present in the lower part of the Illinois Episode stratigraphy is classified to the Vandalia Member till, whereas diamicton in the upper part of the Glasford Formation is interstratified with deposits of sand and gravel or silt and clay and interpreted as ice-marginal and icecontact sediments that were deposited as glaciers of the Illinois Episode melted (Atkinson and others, 2011a,b), and classified to the undifferentiated unit of the Glasford Formation (Stumpf and Dey, in press). Remnants of a second interglacial soil (Sangamon Geosol; Willman and Frye 1970; Follmer and others, 1979) are present in sediments at the top of the Illinois Episode stratigraphy. An organic-rich A soil horizon and/or thin B soil horizon in the paleosol are represented by olive to very dark brown clayey sediments that developed during the Sangamon Episode. 
a
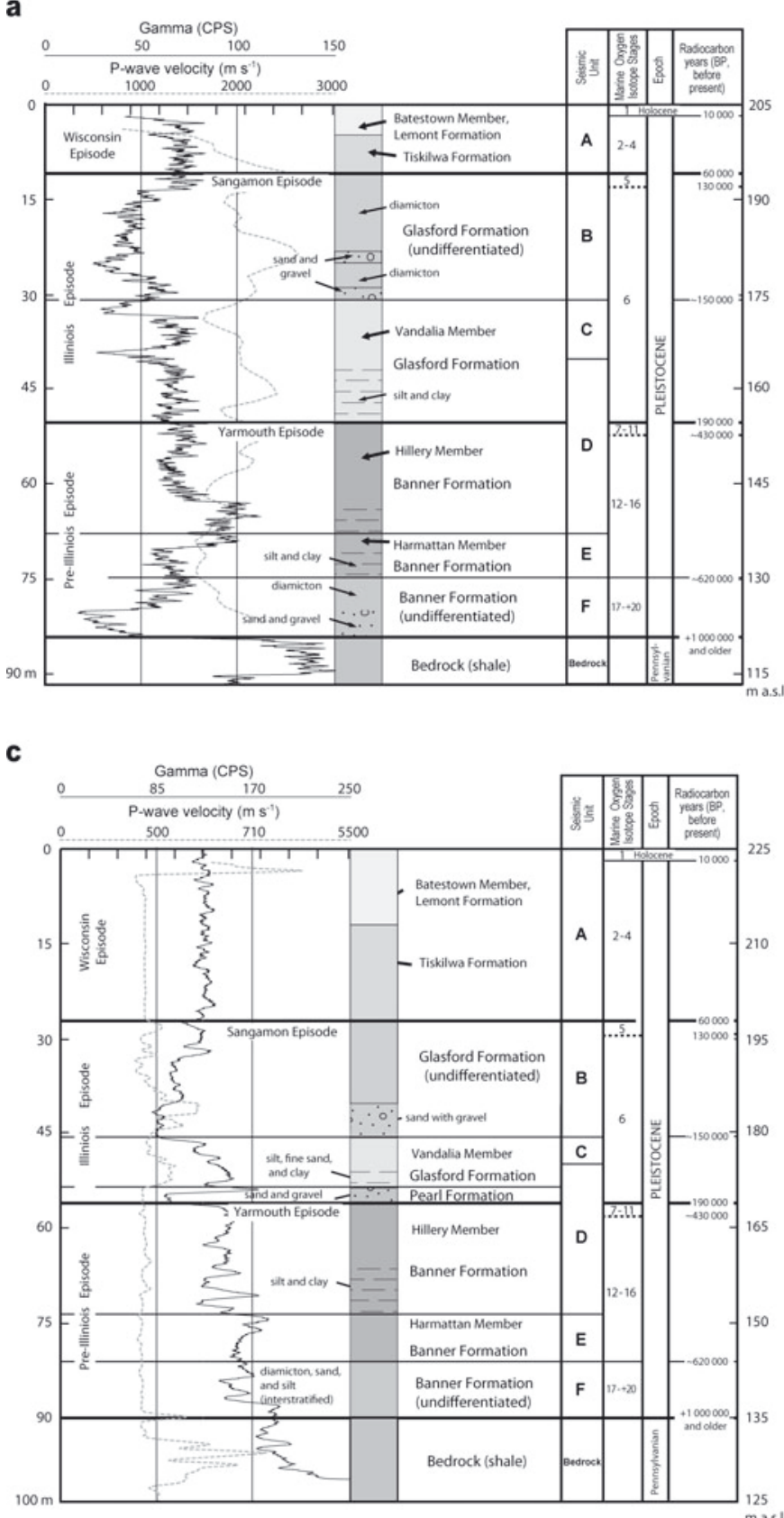

b

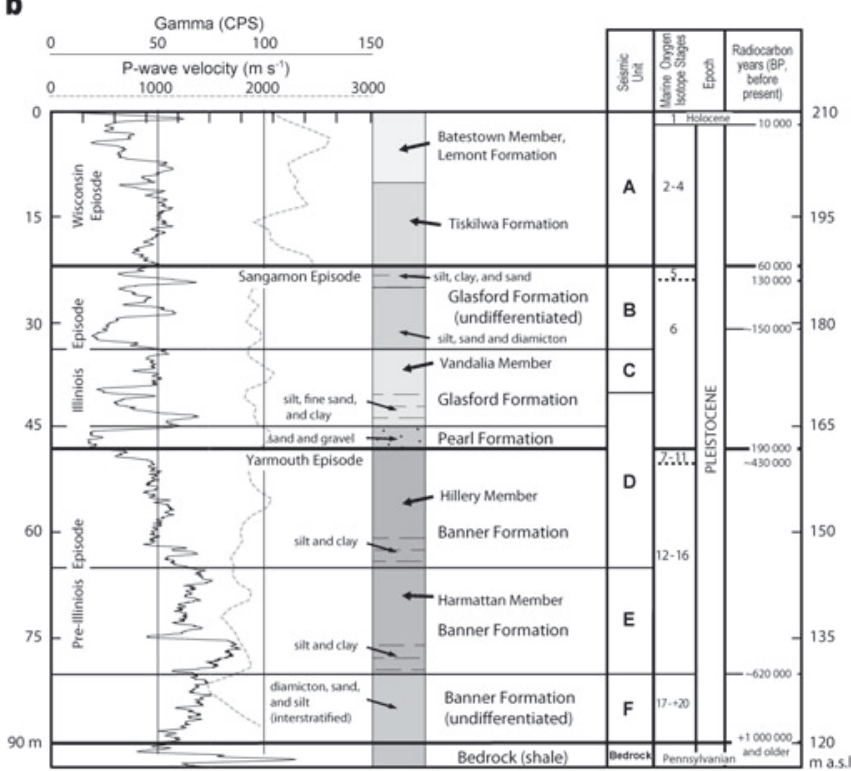

d

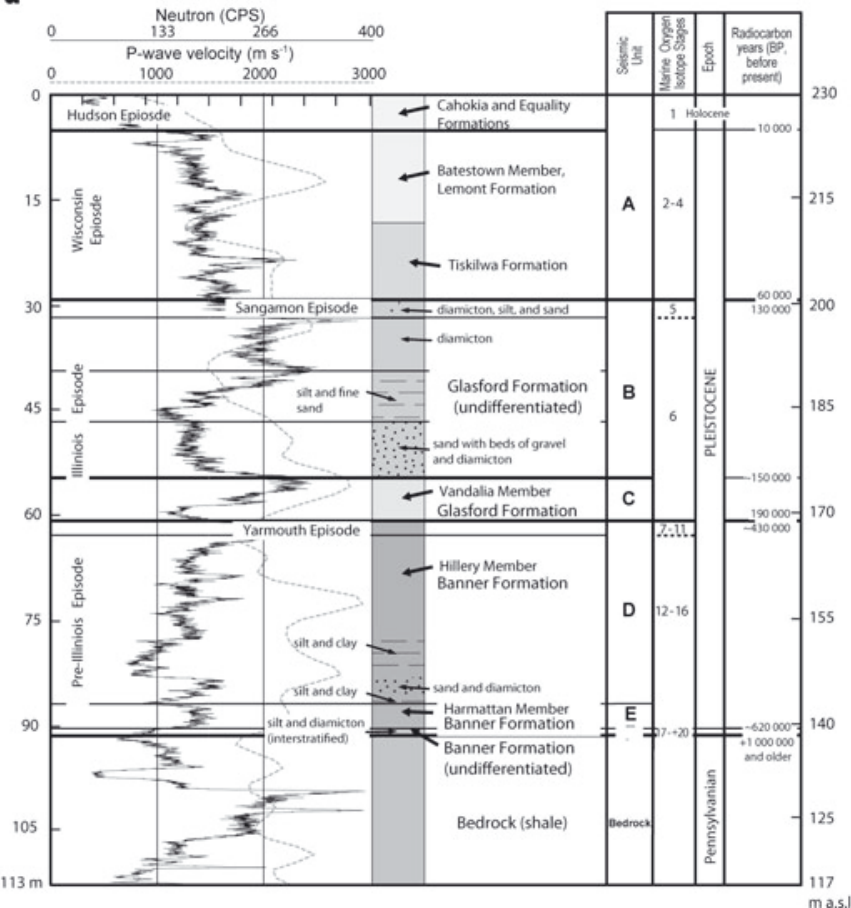

Fig. 2. Geological and geophysical logs for control boreholes over the Pesotum Bedrock Valley and an adjacent bedrock valley under Champaign and Urbana. (a) Borehole 1: $39.943809^{\circ} \mathrm{N}, 88.312500^{\circ} \mathrm{W}$; (b) borehole 2: $40.018116^{\circ} \mathrm{N}, 88.331942^{\circ} \mathrm{W}$; (c) borehole 3: $40.012376^{\circ} \mathrm{N}, 88.274930^{\circ} \mathrm{W}$; and (d) borehole 4: $40.100854^{\circ} \mathrm{N}, 88.229066^{\circ} \mathrm{W}$. The lithostratigraphic units of Stumpf and Dey (in press) are assigned to seismic units and correlated with a diachronic classification and marine oxygen isotope stages of Cohen and Gibbard (2011).

In the study area, deposits of the Illinois Episode are overlain by loam- to silt loam-textured diamictons (tills) classified to the Tiskilwa and Lemont Formations (Fig. 2a-c) deposited during the Wisconsin Episode glaciation (Hansel and Johnson, 1996). Collectively, these tills are 25-35 m thick. The uppermost till, classified to the Batestown Member, Lemont Formation, is the lithology that comprises most of the moraines encountered on land surface (Fig. 1b).

\section{DATA AND METHODS}

HRSR data were acquired along three profiles (710, 801 and 802) totaling $21 \mathrm{~km}$ over the Pesotum Bedrock Valley in central Illinois (Fig. 1b) using a land-streamer system. The land-streamer system comprises $4840 \mathrm{~Hz}$ geophones spaced $3 \mathrm{~m}$ apart, and the source was a $50 \mathrm{~kg}$ accelerated weight drop. The source and streamer were moved at $6 \mathrm{~m}$ intervals, resulting in a 12 common depth point (CDP) fold of coverage.

The seismic data were processed using Landmark Graphics ProMax software. A basic processing scheme was applied to the data following the processing conceptions of Hunter and others (1984), Miller (1992) and Yilmaz (2001). A very careful top mute of the direct and refracted arrivals was applied to avoid interpreting these arrivals as coherent reflector events (Steeples and Miller, 1998). A combination of top mute, bandpass filtering and $\mathrm{f}-\mathrm{k}$ filtering 

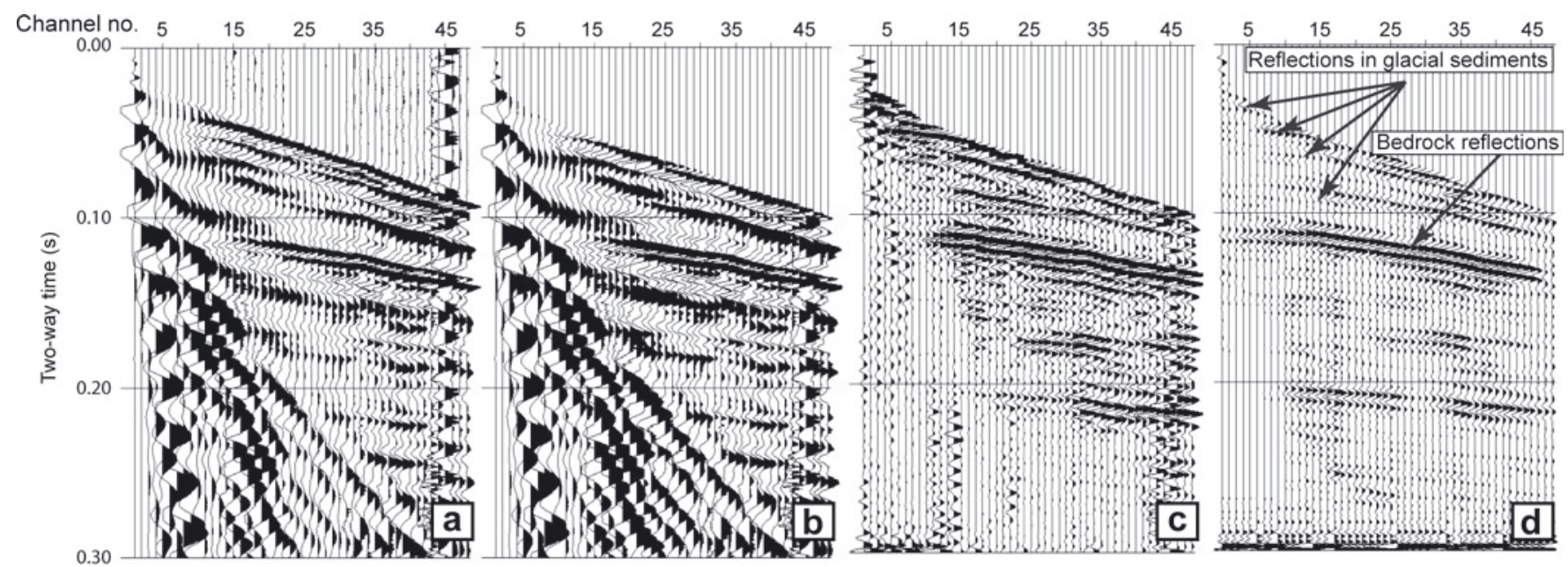

Fig. 3. P-wave land-streamer seismic record from profile 801. A dramatic improvement in signal-to-noise ratio is obtained by processing the data. (a) Raw shot gather, (b) top mute, (c) bandpass filter and automatic gain control (AGC), and (d) f-k filtered.

was effective in suppressing the noise in the data caused by high-frequency airwaves and low-frequency ground roll (Fig. 3). The processed data were imported into the Seismic Micro-Technology Kingdom Suite software for plotting and interpretation.

To facilitate and verify the seismic interpretations, synthetic seismograms were derived from down-hole P-wave velocity data collected by vertical seismic profiling from control boreholes 1 and 2 drilled over the Pesotum Bedrock Valley (Figs 1 and 2a and b). A third borehole was drilled over the valley, but only a P-wave velocity log was collected using a full waveform sonic probe (Fig. 2c). Continuous cores of the sediments and shallow bedrock were obtained in boreholes 2 and 3. In borehole 1, core was not collected; only sieved samples of the drill cuttings were obtained every $0.6 \mathrm{~m}$. These data were compared with measured HRSR data collected at the same borehole location (Fig. 4). This procedure ensures direct correlation between the seismic reflectors and lithological boundaries and supports seismic interpretations. Interpretations of the seismic profiles, based on a mix of seismic stratigraphic and facies analysis, are constrained by sediments encountered in a borehole.

\section{RESULTS}

The P-waves penetrated through the entire valley fill, reaching the more compacted preglacial sediment of the Banner Formation at the bottom of the Pesotum Bedrock Valley and imaging the underlying bedrock surface. The configuration or frequency, amplitude and continuity of the seismic reflections are described and used, in part, to characterize the sediments and bedrock following the procedure of seismic facies interpretation introduced by Mitchum and others (1977) and Sangree and Widmier

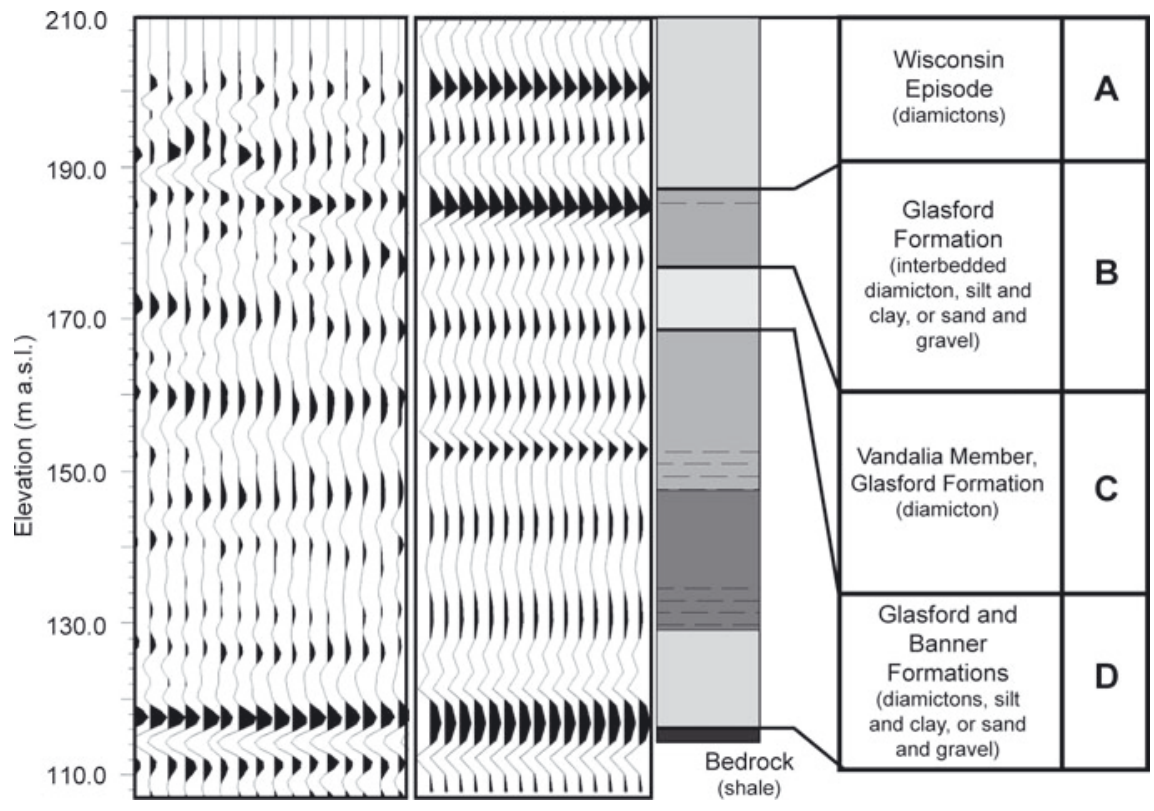

Fig. 4. Correlating the synthetic seismogram generated from the seismic velocity log assuming constant density (middle panel) with the measured seismic reflection data (to the left) from borehole 2 . The generalized log of the geology encountered in the borehole with corresponding diachronic and seismic units is shown on the right. 


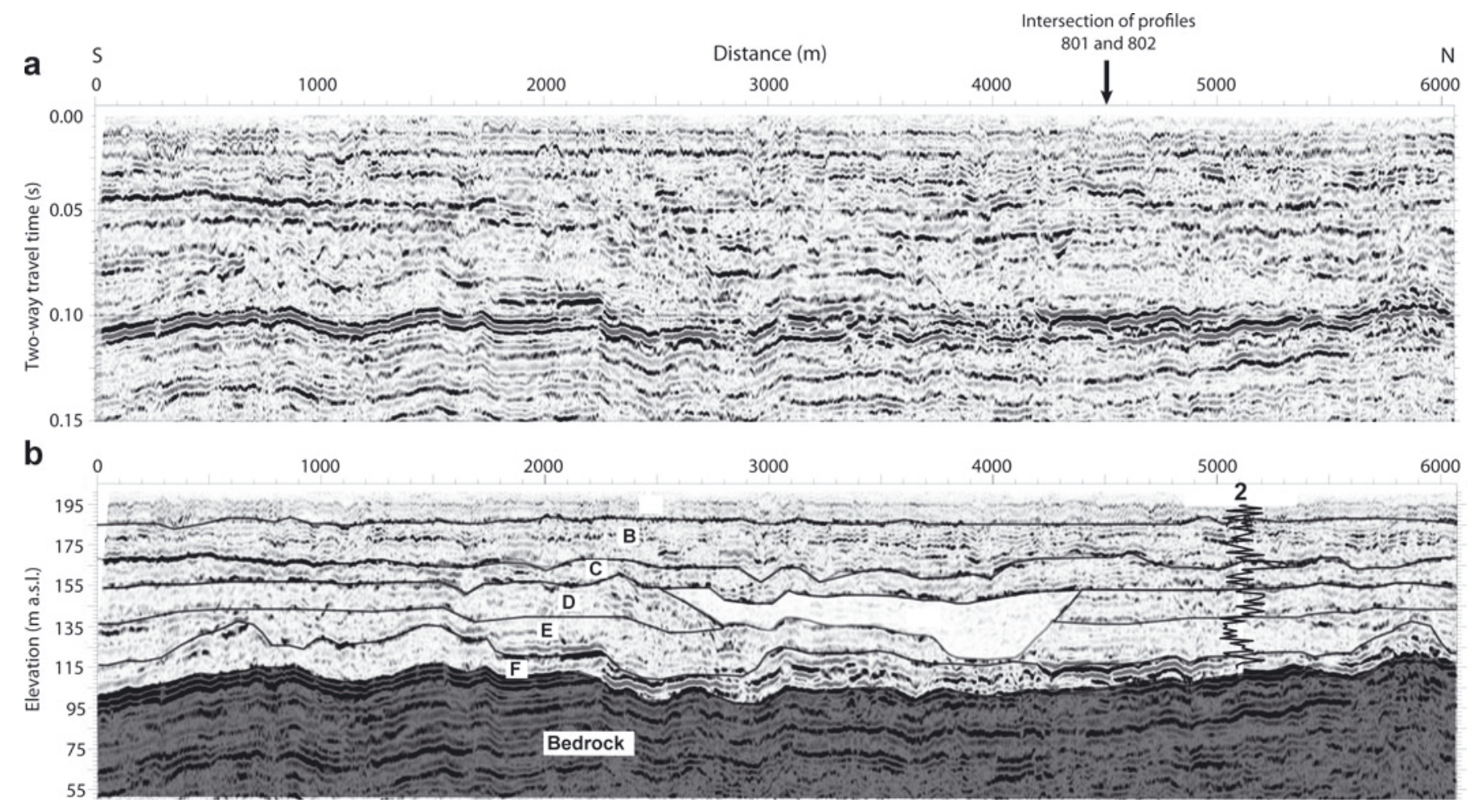

Fig. 5. (a) The time version of the processed P-wave seismic reflection profile 801 and (b) the interpreted depth version of the same profile. The control borehole 2 along the profile and the P-wave seismic velocity log are also shown. The log of the geology in the borehole is provided in Figure 2a. Descriptions of seismic units A-F are provided in the text.

(1979). In this study, the high-amplitude reflectors correspond to the following lithological contacts: (1) the base of Tiskilwa Formation till; and (2) the bedrock surface (Fig. 4). Other reflectors of medium to weak amplitude correspond to other lithological boundaries and intra-unit boundaries, specifically within sediments of the Banner Formation. Accordingly, the sediments were categorized into packages or assemblages informally classified to seven seismo-stratigraphic units (A, B, C, C-1, D, E and F), assigned alphabetically from the land surface to the bedrock (e.g. Figs 5-7).

\section{Seismic unit A}

A continuous strong seismic reflector marks the base of seismic unit A along the profile transects (Figs 5-7). This strong basal reflector, at nearly a constant elevation, marks a

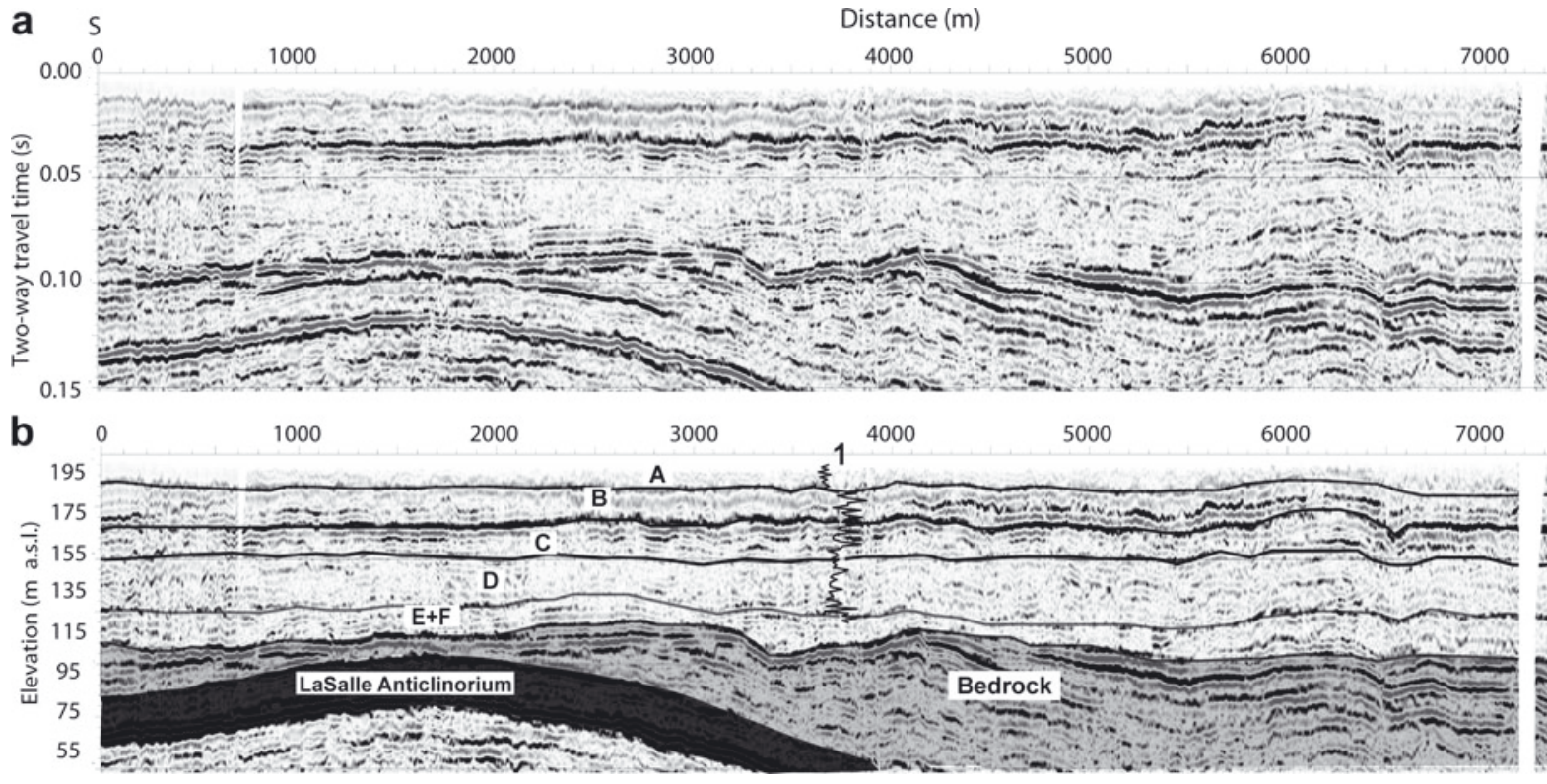

Fig. 6. (a) The time version of the processed P-wave seismic reflection profile 710 and (b) the interpreted depth version of the same profile. The control borehole 1 along the profile and the P-wave seismic velocity log are also shown. The log of the geology in the borehole is provided in Figure 2b. Descriptions of seismic units A-F are provided in the text. 

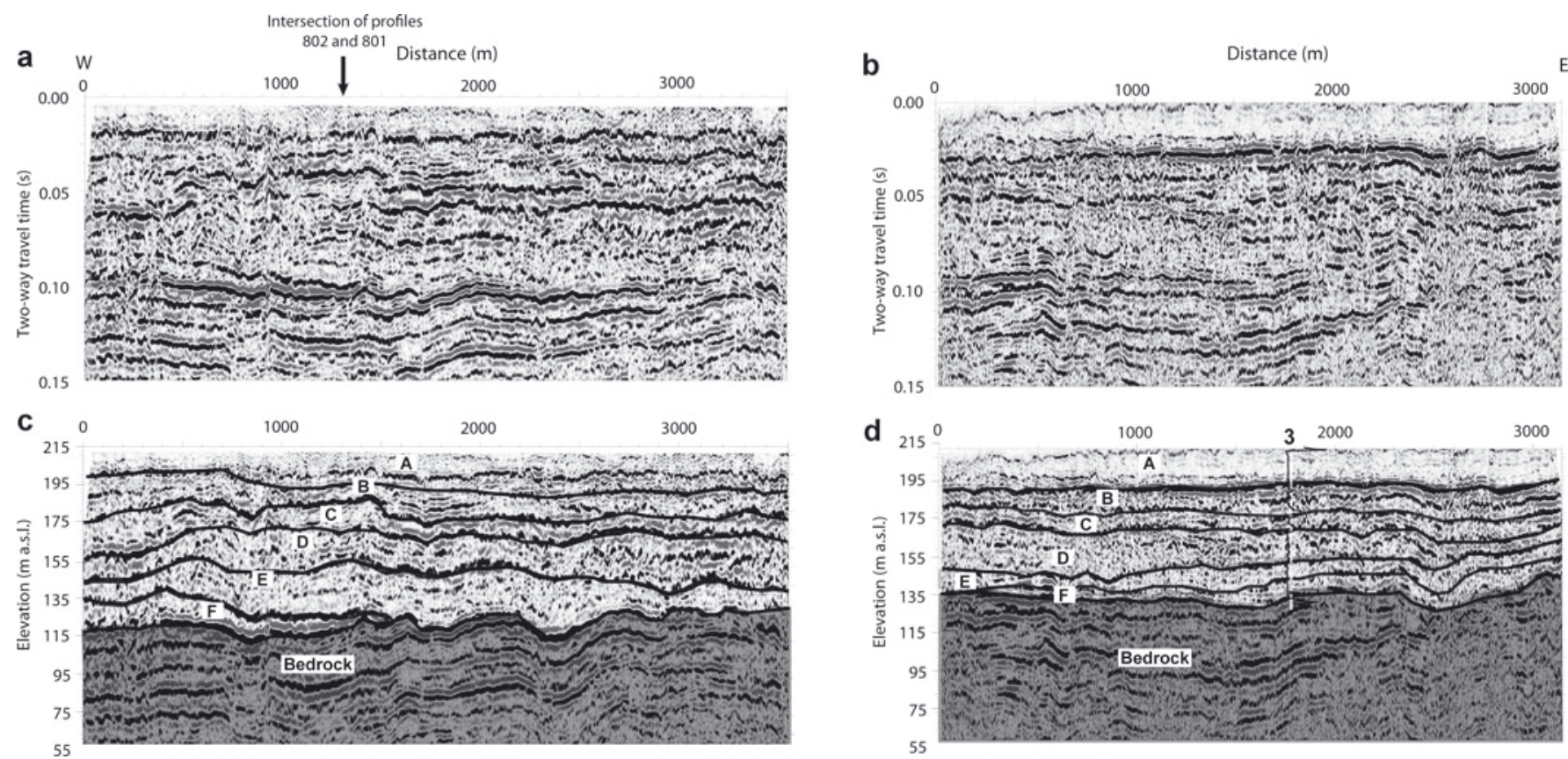

Fig. 7. (a, b) The time version of the processed P-wave seismic reflection profile 802 and $(c, d)$ the interpreted depth version of the same profile. The control borehole 3 along the profile and the P-wave seismic velocity log are also shown. The log of the geology in the borehole is provided in Figure 2c. Descriptions of seismic units A-F are provided in the text.

large velocity contrast with seismic unit B. Based upon available geological and geophysical data along the seismic profiles, seismic unit A includes tills of the Batestown Member (Lemont Formation) and Tiskilwa Formation that were deposited during the Wisconsin Episode glaciation. The thickness of this seismic unit appears to increase towards the north and east part of the study area, reaching a maximum of $23 \mathrm{~m}$ at the northern end of seismic profile 801 (Fig. 6).

\section{Seismic unit B}

Flat-lying, closely spaced and high-amplitude reflections characterize seismic unit B (e.g. Fig. 6). Based upon the borehole geological and geophysical data, seismic unit B includes an assemblage of interstratified layers of diamicton, silt and clay, and sand and gravel classified to the undifferentiated unit of the Glasford Formation. Seismic unit $\mathrm{B}$ is continuous along all the seismic profiles, with welldefined upper and lower boundaries. The seismic unit is $8-$ $23 \mathrm{~m}$ thick.

In seismic profile 801, a decrease in the amplitude of reflectors marking the lower contact of seismic unit B was observed north of $2000 \mathrm{~m}$ (Fig. 5). From the available geological data, the change in seismic properties between seismic units $B$ and $C$ (i.e. the strongest prominent reflectors) is present where sand and gravel classified to seismic unit B overlie diamicton classified to seismic unit C, whereas the weakest reflectors are present where diamictons of each seismic unit overlie each other (Figs $2 b$ and 5 ). The decrease in amplitude at the contact of these seismic units is not continuous, but rather present over short distances separated by higher-amplitude reflectors. The longest interval where the lower amplitudes were measured was along the profile from 4000 to $4700 \mathrm{~m}$ (Fig. 5). The weakest reflectors also extend $\sim 500 \mathrm{~m}$ to the west and east of the intersection with profile 802 (Fig. 8). Here the reflectors lie at higher elevation, $\sim 30 \mathrm{~m}$ above the same reflectors along adjacent parts of profile 801 (Fig. 5).

\section{Seismic units $\mathrm{C}$ and $\mathrm{C}-1$}

Deposits comprising a thin but continuous unit with strong reflectors along the upper and lower boundaries can be traced along the three seismic profiles and are assigned seismic unit $C$ (e.g. Fig. 6). Based on the borehole geological and geophysical data (Fig. 2a-C), seismic unit $\mathrm{C}$ includes diamicton (till) of the Vandalia Member, Glasford Formation, and associated glacial lake sediment (silt, fine sand and clay) deposited prior to the first glacial advance of the Illinois Episode. The seismic properties of these sediments are not significantly different from diamictons of seismic unit $A$ and fine-grained sediment of seismic unit B.

A second seismic unit (C-1) was identified in profile 801 between 2300 and $2800 \mathrm{~m}$ (Fig. 5). High-amplitude reflectors along the top and bottom of the seismic unit mark a significant velocity contrast with the adjacent sediments. Similar velocity contrasts are found between deposits of sand and gravel and silt- or clay-rich sediment (e.g. Pugin and others, 2004). The geological and geophysical data from borehole 2 indicate that seismic unit C-1 may include deposits of sand and gravel that are classified to the Pearl Formation (Fig. 2b). In this borehole, the sand and gravel lies between tills of the Glasford and Banner Formations, but is too thin to resolve on the profile. From seismic reflections in profile 801 (Fig. 5), the sediments classified to the seismic unit appear to be inset into the underlying sediments classified to seismic units D and $\mathrm{E}$.

\section{Seismic unit D}

Moderate-amplitude continuous reflectors characterize seismic unit D (Figs 5-7). From the available geological and geophysical data along the seismic profiles, the unit comprises two deposits: (1) a clay-rich till classified to the Hillery Member, Banner Formation; and (2) a basal layer of bedded to massive silt, fine sand and clay deposited during the pre-Illinoian glaciation (Fig. 2). These sediments have 


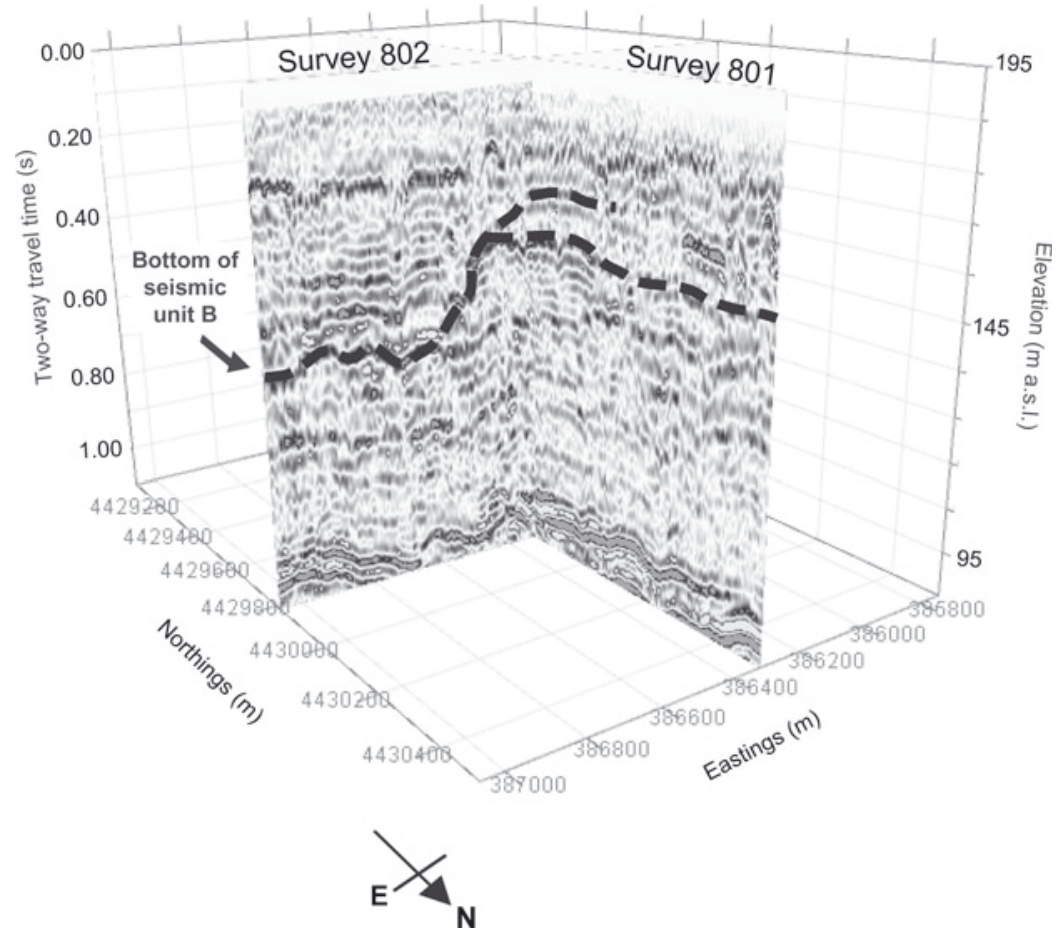

Fig. 8. A view in three dimensions of the intersection between seismic profiles 801 and 802 . The reflectors marking the contact between seismic units $B$ and $C$ significantly increase in elevation towards the intersection from the west.

compacted or hard consistencies and low moisture content. The diamicton is composed of up to $85 \%$ silt and clay (Stumpf and Dey, in press). The two deposits could not have been differentiated solely on the basis of the seismic data.

\section{Seismic unit $\mathrm{E}$}

A pattern of low-amplitude reflections characterizes seismic unit $E$ in the three seismic profiles (Figs 5-7). Seismic unit E could not be differentiated from seismic unit $\mathrm{F}$ in profile 710 . Based on the geological and geophysical data from the control boreholes, this seismic unit includes silt-rich till of the Harmattan Member, Banner Formation, and associated glacial lake sediments (bedded silt, fine sand and clay) that were deposited during the pre-Illinois Episode (Fig. 2a-c). These sediments have compacted or hard consistencies and low moisture contents. The upper boundary of seismic unit $\mathrm{E}$ is poorly delineated over some intervals by the lack of a strong reflector, but overall the seismic reflections of the unit are different from those of the overlying higher reflective sediments. The thickness of seismic unit $\mathrm{E}$ is quite variable, ranging from 3 to $40 \mathrm{~m}$, and increases along the western half of profile 802 where the upper contact of the unit is marked by a prominent reflector (Fig. 7).

\section{Seismic unit $\mathbf{f}$}

Preglacial sediment having low-amplitude reflections is assigned to seismic unit F. Delineating the contact between seismic units $E$ and $F$ was much easier in profile 801 than 802. In profile 801 , there is a highly undulating and partially interconnected upper boundary of seismic unit $F$, which was the only way to distinguish it from the overlying seismic unit E which has similar reflections (Figs 5 and 7). The character of a strong reflector separating the two seismic units suggests a large seismic velocity contrast between them. We were not able to trace the top of unit $F$ in profile 710 , although this contact is marked by a change of lithology in borehole 1
(Fig. 2a). This could be due to the lack of acoustic impedance contrast between sediments of seismic units $E$ and F. However, low-reflectivity sediments of seismic unit F have sufficient contrast with the underlying bedrock surface to delineate the lower contact.

The geological and geophysical data from boreholes in the profiles (Fig. 2a-C) indicate that seismic unit $\mathrm{F}$ includes diamicton, silt, and sand and gravel, sediments deposited during the pre-Illinois Episode bedrock (Stumpf and Dey, in press). These sediments are typically leached of primary carbonate minerals or weakly calcareous and contain numerous clasts of the local bedrock. Localized incision into these sediments, either by water or ice, was identified in profiles 802 and 710 (e.g. Fig. 9). In these areas, narrow channels have been incised into seismic unit $F$. The channel mapped in profile 801 is $500 \mathrm{~m}$ wide and $15 \mathrm{~m}$ deep (Figs 5 and 9), whereas the channel in profile 710 is $800 \mathrm{~m}$ wide (between 3300 and $4100 \mathrm{~m}$ ) and has a maximum depth of $10 \mathrm{~m}$ (Fig. 6).

\section{Bedrock}

The most prominent and laterally coherent reflector observed in the seismic profiles was associated with the upper surface of the bedrock (Figs 5-7) where the contrast in seismic properties, between the bedrock and the overlying sediment of seismic units $E$ and $F$, is the highest. The bedrock surface is somewhat undulating, lying at an elevation of 100-145 ma.s.l. Generally, the elevation of the bedrock surface increases towards the southern and eastern parts of the study area towards the edge of the bedrock valley (Figs 6 and 7).

\section{SUMMARY AND DISCUSSION}

The complex stratigraphy uncovered in the Pesotum Bedrock Valley undoubtedly provides additional information to better 


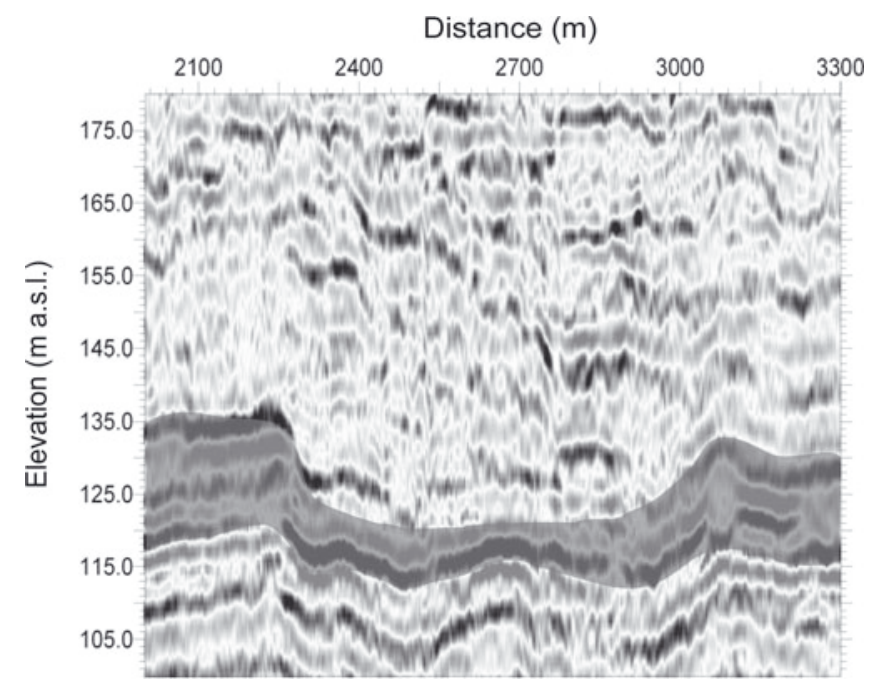

Fig. 9. Close-up view of a small channel eroded into silty and clayey sediments of seismic unit $\mathrm{F}$ along profile 801 . The channel is likely filled with deposits of sand and gravel.

understand the depositional and erosional histories of the Pleistocene glaciations and preglacial times in central Illinois. Integrating HRSR results with drilling and borehole geophysics has allowed us to delineate the spatial distribution of seismic and lithostratigraphic units in order to characterize the sediments comprising the valley fill. This would not have been possible with the available subsurface information from the sparse wide-spaced boreholes over the buried valley.

Buried bedrock valleys in central Illinois have dimensions comparable with buried or tunnel valleys described in glaciated terrain in other parts of North America and northern Europe. Most valleys are tens of kilometers long, hundreds of meters to kilometers wide and have depths ranging from several tens to hundreds of meters. Specifically in this study, the Pesotum Bedrock Valley is $\sim 80 \mathrm{~km}$ long, at least $3 \mathrm{~km}$ at its widest (although the entire width of the valley was not imaged) and incised $60 \mathrm{~m}$ into the bedrock.

Unlike tunnel valleys in northern Europe (e.g. Piotrowski, 1994; Van der Vegt and others, 2012) and those formed during melting of the Laurentide ice sheet during the Wisconsin Episode glaciation (e.g. Ó Cofaigh, 1996; Hooke and Jennings, 2006; Kehew and others, 2012), many buried valleys in central Illinois contain a relatively complete record of the Pleistocene glaciations with little or no evidence of incision by glacial meltwaters, for example Pesotum Bedrock Valley (this study), the unnamed bedrock valley below the cities of Champaign and Urbana (borehole 4 in Figs 1 and 2d), Danville Bedrock Valley (Larson and others, 1997) and Chatsworth Bedrock Valley (Visocky and Schicht, 1969) (Fig. 1). Exceptions to these stratigraphies are in the larger Mahomet and Middle Illinois Bedrock Valleys where thick deposits of sand and gravel (outwash) have been encountered (Kempton and others, 1991; McKay and others, 2008; Stumpf and Dey, in press). These sediments are thought to have been deposited by successive meltwater flows in front of retreating ice margins that have incised into older deposits of finer-grained sediment.

Many of the buried valleys in central Illinois have been filled over the course of multiple glaciations with proglacial lake development in front of advancing ice margins during pre-Illinois and Illinois Episodes. The glacially derived sediments lie over deposits of preglacial riverine sediment and slope wash, or weathered bedrock. The glacial lake sediment is conformably overlain by diamicton deposited in a subglacial environment. Only thin deposits of sand and gravel were encountered below glacial lake sediment or till of the earliest glacial advance during the Illinois Episode. The sedimentary sequence in the Pesotum Bedrock Valley is similar to the buried valleys in the Canadian Prairies containing mud-rich diamicton (Cummings and others, 2012) and some buried bedrock valleys in southern Ontario, Canada (Meyer and Eyles, 2007). Based on the analyses of channels and valley fills by Gibling (2006), these buried valleys are classified as valley fills on bedrock unconformities (B1).

Over these buried valleys, the relatively thick layers of sand and gravel interstratified with diamicton and silt and clay that are classified to the undifferentiated unit of the Glasford Formation (Fig. 2a-c) may indeed fill tunnel valleys. These sediments are interpreted as deglacial deposits associated with melting of the Laurentide ice sheet during the Illinois Episode (Stumpf and Dey, in press). Further, the significant rise in elevation of the lower contact of seismic unit B (Fig. 8) may delineate a buried ice margin associated with this glaciation. Additional investigation will be required to determine the spatial extent and interconnectivity of these deposits of sand and gravel regionally.

The stratigraphic position of glacial lake sediment comprising valley-fill sequences indicates that these valleys were not completely filled in until after the first glacial advance of the Illinois Episode. Prior to being buried, these valleys were sinks for proglacial drainage. The valley fill contains evidence suggesting that drainage along these valleys was blocked multiple times during the pre-Illinois and Illinois Episodes. Further, additional subsurface information in the Teays-Mahomet Bedrock Valley System outside the study area suggests that these glacial lakes of the preIllinois Episodes may not have been confined entirely within tributary valleys to the Mahomet Bedrock Valley. Deposits of silt and clay classified to the Banner Formation encountered occasionally in the Mahomet Bedrock Valley in Illinois (Herzog and others, 1995; Soller and others, 2000; Stumpf and Dey, in press) and the Teays Bedrock Valley in western Indiana (Bleuer, 1991) may be correlative with deposits of fine-grained sediment in the Pesotum Bedrock Valley classified to the Hillery Member, Banner Formation. If so, this proglacial lake may have inundated a much larger area than previously reported (Kempton and others, 1991), occupying the western part of the Teays-Mahomet Bedrock Valley System. Presumably, the dam of either ice or sediment holding back the lake was located in the extreme western part of the Mahomet Bedrock Valley or the Middle Illinois-Mackinaw Bedrock Valleys.

Preliminary calculations suggest that this proglacial lake would have covered an area of $\sim 8500 \mathrm{~km}^{2}$ in Illinois. Although covering a much smaller area than Glacial Lake Agassiz in central North America $\left(840000 \mathrm{~km}^{2}\right.$; Teller and Leverington, 2004) or Vostok Subglacial Lake in Antarctica (>19200 km²; Siegert and others, 2011), the total area inundated is comparable with the size of Glacial Lake Missoula in Montana, USA ( $9700 \mathrm{~km}^{2}$; Petteri and others, 2010), or Glacial Lake Fraser in British Columbia, Canada (>9800 km²; Clague, 1987; Fulton, 1995). Further investigation is required to determine the volume of water held in the lake and its drainage history. 


\section{ACKNOWLEDGEMENTS}

This research was funded by the Illinois State Geological Survey (ISGS), the Illinois State Water Survey (ISWS) and the University of Illinois at Urbana-Champaign through a grant from the Illinois American Water Company. We acknowledge Landmark Graphics as part of the University Grants Program and Seismic Micro-Technology for their software grants. The comments of two anonymous reviewers resulted in considerable improvement of the manuscript. Publication was authorized by the Director, Illinois State Geological Survey.

\section{REFERENCES}

Ahmad J (2006) High resolution seismic and electrical resistivity tomography techniques applied to image and characterize a buried channel (MSc thesis, University of Alberta)

Ahmad J, Schmitt DR, Rokosh CD and Pawlowicz JG (2009) Highresolution seismic and resistivity profiling of a buried Quaternary subglacial valley: Northern Alberta, Canada. Geol. Soc. Am. Bull., 121(11-12), 1570-1583 (doi: 10.1130/B26305.1)

Atkinson L, Ross M, Stumpf M and Ismail A (2011a) Sedimentology and 3-D architecture of subsurface facies of the Illinoian deglaciation in east-central Illinois, USA. In Proceedings of Geohydro 2011 - Joint Meeting of the Canadian Quaternary Association (CANQUA) and the Canadian Chapter of the International Association of Hydrogeologists (IAH-CNC), 28-31 August 2011, Quebec City, Canada http://www.geolhydro2011. ca/gh2011_user/cle_usb?pdf?doc-2199.pdf

Atkinson LA, Ross MA, Stumpf A and Ismail A (2011b) 3-D geological modeling of subsurface facies assemblages correlated to the Illinoian deglaciation in east-central Illinois, United States. Geol. Soc. Am. Abstr., 43(5), 559

Auken E and BURVAL Working Group (2009) Buried Quaternary valleys - a geophysical approach. Z. Deut. Ges. Geowiss., 160(3), 237-247 (doi: 10.1127/1860-1804/2009/0160-0237)

Bleuer NK (1991) The Lafayette bedrock valley system of Indiana; concept, form, and fill. In Melhorn WN and Kempton JP eds. Geology and hydrogeology of the Teays-Mahomet Bedrock Valley systems. (Special Paper 258) Geological Society of America, Boulder, CO, 51-77

Bradford JH, Sawyer DS, Zelt CA and Oldow JS (1998) Imaging a shallow aquifer in temperate glacial sediments using seismic reflection profiling with DMO processing. Geophysics, 63(4), 1241-1247 (doi: 10.1190/1.1444426)

Clague JJ (1987) Quaternary stratigraphy and history, Williams Lake, British Columbia. Can. J. Earth Sci., 24(1), 147-158

Cohen KM and Gibbard P (2011) Global chronostratigraphical correlation table for the last 2.7 million years. Subcommission on Quaternary Stratigraphy, International Commission on Stratigraphy, Cambridge

Cummings DI, Russell HAJ and Sharpe DR (2012) Buried-valley aquifers in the Canadian Prairies: geology, hydrogeology, and origin. Can. J. Earth Sci., 49(9), 987-1004 (doi: 10.1139/ e2012-041)

Curry BB, Grimley DA and McKay EDI (2011) Quaternary glaciations in Illinois. In Ehlers J, Gibbard PL and Hughes PD eds. Quaternary glaciations - extent and chronology: a closer look. (Developments in Quaternary Science 15) Elsevier, Amsterdam, 467-487

Fidlar MM (1943) The preglacial Teays Valley in Indiana. J. Geol., 51(6), 411-418

Follmer LR, McKay ED, III, Lineback JA and Gross DL (1979) Wisconsinan, Sangamonian, and Illinoian stratigraphy in central Illinois (ISGS Guidebook 13). Illinois State Geological Survey, Champaign, IL

Fulton RJ (1995) Surficial materials of Canada. Scale 1:5000000. (Map no. 1880A) Geological Survey of Canada, Ottawa

Gabriel G, Kirsch R, Siemon B and Wiederhold H (2003) Geophysical investigation of buried Pleistocene subglacial valleys in Northern Germany. J. Appl. Geophys., 53(4), 159-180 (doi: 10.1016/j.jappgeo.2003.08.005)

Gibling MR (2006) Width and thickness of fluvial channel bodies and valley fills in the geological record: a literature compilation and classification. J. Sediment. Res., 76(5), 731-770 (doi: 10.2110/jsr.2006.060)

Hall RD and Anderson AK (2000) Comparative soil development of Quaternary paleosols of the central United States. Palaeogeogr., Palaeoclimatol., Palaeoecol., 58(1-2), 109-145 (doi: 10.1016/ S0031-0182(00)00034-1)

Hansel AK and Johnson WH (1996) Wedron and Mason groups: lithostratigraphic reclassification of deposits of the Wisconsin Episode, Lake Michigan Lobe area (1996) (Bulletin 104) Illinois State Geological Survey, Champaign, IL

Hansel AK and McKay EDI (2010) Quaternary period. In Kolata DR and Nimz CK eds. Geology of Illinois. Illinois State Geological Survey, Champaign, IL, 216-247

Herzog B, Stiff B, Chenowith CA, Warner KL, Sieverling JB and Avery CF (1994) Buried bedrock surface of Illinois, 3rd edn. (Map Series 5) Illinois State Geological Survey, Champaign, IL

Herzog BL, Wilson SD, Larson DR, Smith EC, Larson TH and Greenslate ML (1995) Hydrogeology and groundwater availability in southwest McLean and southeast Tazewell Counties. Part 1: aquifer characterization. Cooperative Groundwater Report 17. Illinois State Geological Survey, Champaign, IL

Hooke RLeB and Jennings CE (2006) On the formation of the tunnel valleys of the southern Laurentide ice sheet. Quat. Sci. Rev., 25(11-13), 1364-1372 (doi: 10.1016/j.quascirev.2006.01.018)

Horberg L (1945) A major buried valley in east-central Illinois and its regional relationships. J. Geol., 53(5), 349-359 (doi: 10.1086/ 625294)

Hunter JA, Pullan SE, Burns RA, Gagne RM and Good RL (1984) Shallow seismic reflection mapping of the overburden-bedrock interface with the engineering seismograph: some simple techniques. Geophysics, 49(8), 1381-1385 (doi: 10.1190/1.1441766)

Huuse M and Lykke-Andersen H (2000) Overdeepened Quaternary valleys in the eastern Danish North Sea: morphology and origin. Quat. Sci. Rev., 19(12), 1233-1253 (doi: 10.1016/S02773791(99)00103-1)

Huuse M, Lykke-Andersen H and Piotrowski JA (2003) Geophysical investigations of buried Quaternary valleys in the formerly glaciated NW European lowland: significance for groundwater exploration. J. Appl. Geophys., 53(4), 153-157 (doi: 10.1016/ j.jappgeo.2003.08.003)

Ismail A and Sargent S (2006) Imaging glacial sediments and underlying bedrock in Illinois using surface wave data acquired by a land streamer. In Proceedings of the 2006 Highway Geophysics - NDE Conference, 4-7 December 2007, St Louis, Missouri (UTC Report ETT145) University Transportation Center, University of Missouri-Rolla, Rolla, MO, 286-299

Ismail A, Smith E, Phillips A and Stumpf A (2012) Pitfalls in interpretation of shallow seismic data. Appl. Geophys., 9(1), 87-94

Johnson WH (1986) Stratigraphy and correlation of the glacial deposits of the Lake Michigan lobe prior to 14 ka BP. Quat. Sci. Rev., 5(1), 17-22 (doi: 10.1016/0277-3791(86)90170-8)

Jørgensen F and Sandersen PBE (2008) Mapping of buried tunnel valleys in Denmark: new perspectives for the interpretation of the Quaternary succession. Geol. Surv. Den. Greenl. Bull., 15, 33-36

Jørgensen F, Lykke-Andersen H, Sandersen PBE, Auken E and Nørmark E (2003) Geophysical investigations of buried Quaternary valleys in Denmark: an integrated application of transient electromagnetic soundings, reflection seismic surveys and exploratory drillings. J. Appl. Geophys., 53(4), 215-228 (doi: 10.1016/j.jappgeo.2003.08.017)

Kehew A, Piotrowski JA and Jørgensen F (2012) Tunnel valleys: concepts and controversies - a review. Earth-Sci. Rev., 113(1-2), 33-58 (doi: 10.1016/j.earscirev.2012.02.002)

Kempton JP, Johnson WH, Heigold PC and Cartwright K (1991) Mahomet Bedrock Valley in east-central Illinois: topography, glacial drift stratigraphy, and hydrogeology. In Melhorn WN and 
Kempton JP eds. Geology and hydrogeology of the TeaysMahomet Bedrock Valley systems. (Special Paper 258) Geological Society of America, Boulder, CO, 91-125

Kilner M, West LJ and Murray T (2005) Characterisation of glacial sediments using geophysical methods for groundwater source protection. J. Appl. Geophys., 57(4), 293-305 (doi: 10.1016/ j.jappgeo.2005.02.002)

Kolata DR (2010) Overview of Illinois geology. In Kolata DR and Nimz CK eds. Geology of Illinois. Illinois State Geological Survey, Champaign, IL

Kristensen TB, Huuse M, Piotrowski JA and Clausen OR (2007) A morphometric analysis of tunnel valleys in the eastern North Sea based on 3D seismic data. J. Quat. Sci., 22(8), 801-815 (doi: 10.1002/jqs.1123)

Larson DR, Kempton JP and Meyer S (1997) Geologic, geophysical, and hydrologic investigations for a supplemental municipal groundwater supply, Danville, Illinois. (Cooperative Groundwater Report 18) Department of Natural Resources/Illinois State Geological Survey and Illinois State Water Survey, Champaign, IL

Larson TH, Phillips AC, Sargent SL and Hardy F (1999) Mapping shallow fluvial and glaciofluvial deposits in Illinois using 2-D resistivity and GPR. Geol. Soc. Am. Abstr., 31(7), 143

Leverett F (1898) The Weathered Zone (Yarmouth) between the Illinoian and Kansan till sheets. J. Geol., 6(3), 238-243

McKay EDI, Berg RC, Hansel AK, Kemmis TJ and Stumpf AJ (2008) Quaternary deposits and history of the ancient Mississippi River valley, north-central Illinois. (ISGS Guidebook 35) Illinois State Geological Survey, Champaign, IL

Meyer PA and Eyles CH (2007) Nature and origin of sediments infilling poorly defined buried bedrock valleys adjacent to the Niagara Escarpment, southern Ontario, Canada. Can. J. Earth Sci., 44(1), 89-105 (doi: 10.1139/e06-085)

Miller R (1992) Normal moveout stretch mute on shallow-reflection data. Geophysics, 57(11), 1502-1507 (doi: 10.1190/1.1443217)

Mitchum RMJ, Vail PR and Thompson S, III (1977) Seismic stratigraphy and global changes of sea level: Part 2. The depositional sequence as a basic unit for stratigraphic analysis. In Payton CE ed. Seismic stratigraphy: applications to hydrocarbon exploration. (AAPG Memoir 26) American Association of Petroleum Geologists, Tulsa, OK, 53-62

Musil M and 6 others (2002) Shallow seismic surveying of an Alpine rock glacier. Geophysics, 67(6), 1701-1710 (doi: 10.1190/1.1527071)

Nelson WJ (1995) Structural features in Illinois. (Bulletin 100) Illinois State Geological Survey, Champaign, IL

Ó Cofaigh C (1996) Tunnel valley genesis. Progr. Phys. Geogr., 20(1), 1-19 (doi: 1177/030913339602000101)

Petteri A, Baker VR and Smith LN (2010) Paleohydraulic reconstruction of the largest Glacial Lake Missoula draining(s). Quat. Sci. Rev., 29(23-24), 3067-3078 (doi: 10.1016/j.quascirev.2010.07.015)

Piotrowski JA (1994) Tunnel-valley formation in northwest Germany - geology, mechanisms of formation and subglacial bed conditions for the Bornhöved tunnel valley. Sediment. Geol., 89(1-2), 107-141 (doi: 10.1016/0037-0738(94)90086-8)

Pugin AJM and Pullan SE (2011) Seismic reflection surveying in regional hydrogeology: an example from the Montérégie region, Quebec. In Proceedings of Geohydro 2011 - Joint Meeting of the Canadian Quaternary Association (CANQUA) and the Canadian Chapter of the International Association of Hydrogeologists (IAHCNC), 28-31 August 2011, Quebec City, Canada http:// www.geohydro2011.ca/gh2011_user/cle_usb/pdf/doc-2353.pdf

Pugin AJM, Larson TH, Sargent SL, McBride JH and Bexfield CE (2004) Near-surface mapping using SH-wave and P-wave seismic land-streamer data acquisition in Illinois, U.S. Leading Edge, 23(7), 677-682 (doi: 10.1190/1.1776740)

Pugin AJM, Pullan SE, Hunter JA and Oldenborger GA (2009) Hydrogeological prospecting using P- and S-wave landstreamer seismic reflection methods. Near Surf. Geophys., 7(5-6), 315-327 (doi: 10.3997/1873-0604.2009033)

Reitner JM, Gruber W, Römer A and Morawetz R (2010) Alpine overdeepenings and paleo-ice flow changes: an integrated geophysical-sedimentological case study from Tyrol (Austria). Swiss J. Geosci., 103(3), 385-405 (doi: 10.1007/s00015-0100046-9)

Saines M (1968) Map interpretation and classification of buried valleys. Ground Water, 6(4), 32-37 (doi: 10.1111/j.17456584.1968.tb01654.x)

Sangree JB and Widmier JM (1979) Interpretation of depositional facies from seismic data. Geophysics, 44(2), 131-277 (doi: 10.1190/1.1440957)

Sharpe DR, Pugin A, Pullan SE and Gorrell G (2003) Application of seismic stratigraphy and sedimentology to regional hydrogeological investigations: an example from Oak Ridges Moraine, southern Ontario, Canada. Can. Geotech. J., 40(4), 711-730 (doi: 10.1139/t03-020)

Siegert MJ, Popov S and Studinger M (2011) Vostok subglacial lake: a review of geophysical data regarding its discovery and topographic setting. In Siegert MJ, Kennicutt $\mathrm{MCl}$ and Bindschadler RA eds. Antarctic subglacial aquatic environments. (Geophysical Monograph Series 192) American Geophysical Union, Washington, DC, 45-60

Smith RC and Sjogren DB (2006) An evaluation of electrical resistivity imaging (ERI) in Quaternary sediments, southern Alberta, Canada. Geosphere, 2(6), 287-298 (doi: 10.1130/ GES00048.1)

Soller DR, Price SD, Kempton JP and Berg RC (2000) Threedimensional geologic maps of Quaternary sediments in eastcentral Illinois. (USGS IMAP 2669) US Geological Survey, Reston, VA

Stackebrandt W (2009) Subglacial channels of Northern Germany - a brief review. Z. Deut. Ges. Geowiss., 160(3), 203-210 (doi: 10.1127/1860-1804/2009/0160-0203)

Steeples DW and Miller RD (1998) Avoiding pitfalls in shallow seismic reflection surveys. Geophysics, 63(4), 1213-1224 (doi: 10.1190/1.1444422)

Stumpf AJ and Dey WS (in press) Understanding the Mahomet aquifer: geological, geophysical and hydrogeological studies in Champaign County and adjacent areas. (Contract report to the Illinois-American Water Company.) Illinois State Geological Survey, Champaign, IL

Teller JT and Leverington DW (2004) Glacial Lake Agassiz: a 5000 $\mathrm{yr}$ history of change and its relationship to the $\delta^{18} \mathrm{O}$ record of Greenland. Geol. Soc. Am. Bull., 116(5-6), 729-742 (doi: 10.1130/B25316.1)

Van der Veen M and Green AG (1998) Land streamer for shallow seismic data acquisition: evaluation of gimbal-mounted geophones. Geophysics, 63(4), 1408-1413 (doi: 10.1190/ 1.1444442)

Van der Veen M, Spitzer R, Green A and Wild P (2001) Design and application of a towed land-streamer system for cost-effective 2-D and pseudo-3-D shallow seismic data acquisition. Geophysics, 66(2), 482-500 (doi: 10.1190/1.1444939)

Van der Vegt P, Janszen A and Moscariello A (2012) Tunnel valleys: current knowledge and future perspectives. In Huuse $M$, Redfern J, Le Heron DP, Dixon RJ, Moscariello A and Craig J eds. Glaciogenic reservoirs and hydrocarbon systems. (Special Publication 368) Geological Society, London

Ver Steeg K (1946) The Teays River. Ohio J. Sci., 46(6), 297-307

Visocky AP and Schicht RJ (1969) Groundwater resources of the buried Mahomet Bedrock Valley. (Report of Investigation 62) Illinois State Water Survey, Champaign, IL

Willman HB and Frye JC (970) Pleistocene stratigraphy of Illinois. (Bulletin 94) Illinois State Geological Survey, Champaign, IL

Yilmaz Ö (2001) Seismic data analysis: processing, inversion and interpretation of seismic data. (Investigations in Geophysics 10) Society of Exploration Geophysicists, Tulsa, OK 